\title{
Motivation, an Engine for Organizational Performance, a case Study of Lagos State University, External System.
}

\author{
${ }^{1}$ Olusanya Samuel Olumuyiwa, ${ }^{2}$ Awotungase, Suleiman Adelaja and \\ ${ }^{3}$ Oyebo, Afees Oluwatosin. \\ ${ }^{1}$ Lecturer Lagos State University External system,ECONOMICS DEPARTMENT. \\ ${ }^{2}$ Lecturer Lagos State University External system BUSINESS ADMINISTRATION DEPARTMENT \\ Associate Lecturer Saint Augustines' College of Education Akoka \\ ${ }^{3}$ Lecturer Lagos State University External system MARKETING DEPARTMENT \\ PENSION OFFICER, LAGOS STATE PENSION COMMISION.
}

\begin{abstract}
The research study takes a look at motivation, an engine for organizational performance, a case study of Lagos State University, External System. However, the study make use of primary data and questionnaire were distributed to one hundred and fifty resource person (lecturers) in Lagos State University, external system and Spearman's rank Correlation coefficient was adopted as the estimation techniques. More so, the objectives of the study examine whether motivation affects individuals lecturer's performance in Lagos State University External System, and to also examine whether job satisfaction enhances productivity among the lecturer's in Lagos State University, External system. Further more, the result of the study reveals that motivation plays a lot of role in affecting individual lecturers' performance in Lagos State University, external system and at the same time Job satisfaction has not enhances productivity among the lecturer's in Lagos State University, External system, and that many resource person (lecturers) in LASU external system are not happy with the system and the way it is been coordinated, according to them, bad leadership. Therefore, the study recommend and conclude that the lecturers have need for affection, achievement, recognition, and advancement at work and any attempt that makes all these not present will cause job dissatisfaction to the entire resource person (lecturers) in LASU, external system, therefore the director of the programme should endeavor to improve on the welfare of the resource person (lecturers) for better productivity to take place in the system.
\end{abstract}

Keywords: Lagos State University, External System, Motivation, Productivity, Resource Person.

\section{Introduction}

Motivation is a frequency used but a poorly understandings term. Over one hundred and forty definitions have been provided over the years, and noted scholars of work motivation have said that trying to define "Motivation" often gives them a severe "stomach ache". This remark may be a bit of an exaggeration, but it underscores the need to get a firm grasp of what motivation is beefier we try to understand its role in understanding and managing organizational bahaviour (Gareth and George, 1999).

According to Luthans (2002), the term motivation can be traced to the Latin word MOVERE, which means "to move". This meaning is evident in the following comprehension definition: motivation is a process that stars with a physiological deficiency or need that activates behaviour or a drive that is aimed at a goal or incentive, thus, the key to understanding the process of motivation lies in the meaning of, and relationships among, needs, drive and incentives.

The concept of work motivation is important because it explains why workers behave as they do. Motivation, therefore, is a psychological forces within a person that determine the direction of a person's behaviour in an organization, a person's level of effort and level of persistence. (Gareth and George, 1999).

Robbins (1998) defines work motivation as the willingness to exert high level of effort towards organizational goals, conditional by the effort's ability to satisfy some individual need.

Kuye (2001) asserts further what Robbins said earlier that motivation emanates when an individual willingly exerts greater effort to achieve organizational goals, conditioned by the effort's capacity to satisfy individual's need. He defines work motivation as the willingness to exert greater effort to achieve organizational goals, adding that, any influence that directs individual is goal-directed behavoiur.

According to Rollinson et al (1998), work motivation means a state arising in process that is internal and external to the individual, in which the person perceives that is appropriate to pursue a certain course of action(s) directed at achieving a specified outcome(s) and in which the person choose to pursue those outcomes with a degree of vigour and persistence. The concept has a long history in psychological principles: first, that all physical activity-behaviour is preceded by mental actions of some sort; second, that all behavoiur is goal directed and aims to achieve some desired state of affairs, and thirdly, that there an element of hedonism in 
which the individual seeks to maximize pleasure and minimize pains or unpleasantness. Campbell and Pritched (1976), as well as Porter and Lawler (1968) describe work motivation as a process that drives the individual to voluntarily produce in his work. While the concept of job satisfaction is a pleasurable or positive emotional state result from the appraisal of one's job or job experiences (Locke, 1976) Hackett (1979) sees job satisfaction as the value place in the work itself as a means of motivation people. He further explains that the importance of intrinsic motivation, which gives careful attention to how job are designed and the managerial policies of the organization in such a way that employees drive maximum satisfaction of their needs through them.

According to George and Gareth (1999) job satisfaction is the collection of feelings and beliefs that people have about their current jobs. They assert further that employees' levels or degrees of job satisfaction can range from extreme to satisfaction extreme dissatisfaction. In addition to having attitudes about their jobs as a whole, people also can have attitudes about various aspects of their jobs- such as the kind of work they do; their co-workers, supervisors, or subordinate and their pay.

Lacke (2002) gives a comprehensive definition of job satisfaction as involving cognitive, effective and evaluation reactions or attitudes and stars; I is "a pleasure or positive emotional state resulting from the appraisal of one's job or job experience". Job satisfaction, however, is a result of employees' perception of how well their job provides those things that are viewed as important. It is generally recognized in the organizational behaviour field that job satisfaction is the most important and frequently studied attitude.

However, in today's corporate organizations, there is the argument as to what actually influences and induces employees' level of productivity. Work motivation, job satisfaction and good leadership are believed to be a lasting solution to employees' absenteeism, turnover, and decline in productivity. However, in work content, motivation is an abstract topic to social scientists. To managers, motivation has a much stronger practical significance, everything achieved in or by an organization ultimately depends on human activity. Managers, therefore, are vitally concerned with having subordinates, who willingly and effectively channel their energies into performing their allotted tasks. Basically, what prompts someone or individual to join a firm in the first place is the possibility that he or she will be able to satisfy certain personal needs and wants.

However, majority of organization in Nigeria do not employ good leadership to handle their work and this will also go along way affect the performance of the organization negatively because the belief is that with good motivation and leadership an organizational performance will be enhanced. In view of the aforementioned observations, this study will then find out what impact does work motivation and leadership will affect organization performance.

Further more, the study tends to examine whether motivation affects individuals lecturer's performance in Lagos State University External System, and to also examine whether job satisfaction enhances productivity among the lecturer's in Lagos State University, External system.

\section{Brief Literature Review}

Luthans, (2002) states that motivation could be traced back to the Latin word "MOVERE," which means "to move". He explained further what the concept of work motivation cannotes; saying that work motivation is a process that starts with physiological or psychological deficiency or need that activates a behaviour or a drive that is aimed at a goal or incentive. This, the key to understanding the process of motivation lies in the meaning of, and, relationships among, needs, drives and incentive. According to Robbins (1998) the concept of work motivation defines as the willingness to exert high levels of effect towards oorganizational goals, conditioned by the efforts ability to satisfy some individual needs.

Motivation is a basic psychological process which helps to understand the motive behind human behaviour i.e why people behave the way they do. It should however be noted that motivation is a driving force and should not be equated with behaviour. It represents those psychological processes that arouse, directs and sustains or maintains an individual voluntarily actions which are directed towards the attainment of a goal from organization behaviour point of view.

Kuye (2001) reaffirms and acknowledges Robbins on work motivation, adding that when an individual willingly exerts greater effort to achieve organizational goals, conditioned by the effort's capacity to satisfy the individual's need, there is motivation. This, motivation, is the willingness to exert greater effort to achieve organizational goals, and any influence that directs individual's goal-directed behaviour.

Derk et.al (1998) define work motivation as a state arising in processes that are internal and external to the individual, in which the person perceives that it is appropriate to pursue a certain course of action (or actions) directed at achieving a specified outcome(s) and in which the person chooses to pursue those outcomes with a degree and persistence.

In psychology, however, motivation is essentially an explanatory concept, and is used to explain why a person behaves in a certain way and, in particular, to describe three components of behaviour that have an impact on performance, direction of behaviour, which is greatly influenced by what a person most desire to do; 
intensity of behaviour, which roughly equates to how hard the individual's willingness to stay with the direction when obstacles are encounter.

Management scholars as well as Organizational Behaviourist describe work motivation as a process which dives the individual to voluntarily produce effort in his work. (Campbell and Pritchard, 1976; Grean, 1969; Lawler, 1964; Porter and Lawler, 1968). However, they propose an explanation of motivated behaviour that can be observed through effort displayed at work. According to Nadler and Porter, (1977) their concern was on interactions between compensation, work motivation and on satisfaction.

This explains the link between behaviour and attitudes and in particular between efforts, which indicates motivation, and job satisfaction is however described as the collection of feelings and beliefs that people have about the current jobs (George and Gareth, 1999).

Luthans (2002) posits further that job satisfaction is a pleasurable or positive emotional state resulting from the appraisal of one's job or job experience. Jobs satisfaction is a result of employees' perception of how well their jobs provide those things that are viewed as important. According to Luthena, adding that it is generally recognized in the organizational behaviour field that job satisfaction is the most important and frequently studied attitude. Job satisfaction is an emotional response to a job situation, as such; it cannot be seen but can only be inferred. It is often determined by how well outcomes meet or exceed expectations. Fir instance, if employees feel that they are working much harder than others in their department but are receiving fewer rewards, they will perhaps have a negative attitude towards the work, the boss, and/or co-workers and job dissatisfaction will emanate. On the other hand, if they feel they are being treated very well and are being paid equitably, they are likely to have a positive attitude towards the job, thereby resulting in job satisfaction.

Job satisfaction represents several related attitudes through the years; five job dimensions have been identified to represent the most important characteristics of $\mathrm{s}$ job about which employees have effective's response. They are:

* The work itself: Extent to which the job provides an individual with interesting tasks, opportunities for learning and the chance to accept responsibility.

* Pay: The amount of financial remuneration that is and the degree to which this is viewed as equitable vis-àvis that of others of the organization.

* Promotion Opportunities: The chances for advancement in the organization..

* Supervision: The abilities of supervision to provide technical assistance and behaviour support.

* Co-Workers: The degree to which fellow workers are technical proficient and socially supportive.

\section{Work Motivation Approaches}

Content and process theory to work motivation, contemporary theories to work motivation. The content theory is the earliest perspective before the process theory which examines what are the contents of an individual that create and sustain his motivation i.e. the contents of an individual job that motivates.

\section{Abraham Maslow's Hierarchy of Needs}

It is probably safe to conduct that the most well-known theory of motivation is Abraham Maslow's hierarchy of needs. He hypothesized that within every human being their exists a hierarchy of five needs is peculiar to all types of human being and these are:

Physiological Needs: The most basic level in the hierarchy is the physiological needs, generally corresponds to the unlearned primary needs discussed earlier. The needs of hunger, thirst, sleep and ser are some examples. According to the theory, once basic needs are satisfied, they no longer motivated, for example, a starving person will strive to obtain a carrot that is within reach. However, after eating his or her fill of the carrot, the person will not be motivated only by the next higher level of needs. Safety Needs: It is otherwise known as psychological need which is the second level of needs. These include for need for safety and security, both physical and emotional, job security, safe, working conditions absence of fears to worries on the job. The whole organism, according to Maslow in Luthans, (2002) may become a safety- seeking mechanism. Yet is true of the physiological needs, once these safety needs are satisfies, they no longer motive.

Affiliation Needs: Otherwise called live and belongingness needs, are the desires for friendship, love, and belonging. This level in Maslow's hierarchy of needs represents a clears step up from the truly basic physiological and security needs. Employees with high affiliation needs enjoy working closely with others. Employees with low affiliation needs may be content to work on tasks by themselves.

McCuddy, K (2001) says that when an organization does not meet affiliation needs, an employee's dissatisfaction may be expressed in terms of frequent absenteeism, low productivity, stress- related behaviour, and even emotional breakdown.

Esteems Needs: It describes the need for power, need for recognition, needs for self-esteem, desires for sell-respect sense of personal achievement, and recognition from others. Maslow posits in McCuddy, Michael, that individual seek opportunities, to satisfy these needs for competence and worth. He argues further that 
managers who perceive that employed are motivated by esteem needs emphasize the handwork and finely honed skills that are required for success. They may publicity reward achievement with published achievement lists, bonus, praise, lapel pins, and articles in the organizations paper. These and other forms of recognition help to built employee pride. When the need for esteem is dominant, managers can promote job satisfaction and high quality performance by providing opportunities for exciting, challenging work and recognition for accomplishment. Self-Actualization Needs: It describes needs and desires of an individual for personal growth, self fulfillment, and the realization of the individual's full potential.

As self-actualized person accepts both the self an others traits commonly exhibited include initiative, spontaneity, and problem-solving ability. Managers who recognize this level of motivation in employees can help them discover the growth opportunities inherent in their jobs. For examples managers can create a motivation environment by involving employees in the decision-making process, restructuring their jobs, or offering them special assignments which call for special skills.

\section{Core Assumption of Maslow's Needs Hirearchy}

Maslow's hierarchy of needs rests on four basic assumptions A satisfied need is longer a motivator. Once a need is satisfied, another emerges to take its place. Thus people are always striving to satisfy some higher need.

The needs network for most people is complex. That is, various needs affect a person's behaviour at the same time. The general, lower level needs must be satisfied before higher level needs become strong enough to stimulate behaviour. These are many more ways to satisfy higher local needs than there are to satisfy lower level needs.

\section{Criticism of Maslow Hierarchy of Needs Its Implication for Managers.}

- Individuals are motivated by different needs at different time.

- And that satisfaction of a lower need does not elongate its proponent.

A useful insight into this model is that managers are able to appreciate various categories of human needs and that the best thing to do is to identify the various components at work situations what would satisfy that various needs in other to motivate workers. The basic is that, the lower order needs tend to provide a very stronger motivation to individuals at the lower ring of the organization hierarchy. And of course, the higher order needs provide stronger motivation for barker at the top level of organization or management.

\section{Alderfer's Existence Reletedness and Growth Theory}

Claton Alderfer's Existence, Relatedness. Growth (ERG) theory is also a need theory on work motivation. Alderfer's theory builds on some of Maslow's thinking but redness the number of universal needs from fire to three and is more flexible in terms of movement between levels Like Maslow, Alderfer also proposes that needs can be arranged in a hierarchy.

Whereas Maslow assumes that lower-level needs must be satisfied before a higher-level need is a motivator, Alderfer lifts this restriction. According to ERG theory, a higher-level need can be motivator even if a lower-level need even if a lower-level is not fully satisfied and, needs at more than one level can be motivators at any time.

Alderfer aggress with Maslow that as lower-level needs are satisfied, a worker becomes motivated to satisfy higher-level needs. Alderfer breaks with Maslow on the consequences of need frustration. Maslow says that once a lower-level need is satisfied, it is no longer a source of motivation. While Alderfer proposes that when an individual is motivated to satisfy a higher-level but has difficulty doing so, the person's motivation to satisfy lower-level needs will increase.

\section{Herzberg's Two Factor Model: A content Approach}

This theory describes the characteristics of work and work environment that affect job satisfaction and performance. Considerable research has been conducted on the subject performance appraisal, including various characteristics of performance appraisal systems e.g. number of rating categories, types of standard used, linkage with pay decisions; (Landy \& Farr, 1980) Murphy, K.R \& (1995).

In a more recent review of the current state of performance appraisal research, Bretz, Milkorich and Read (1992) identified degree of rating segmentations, that is, number of rating categories as a characteristics in need of study because of the possibility that it may influence employee motivation or work attitudes.

According to Koontz et. al, (1980) they assist that Hertzberg's research purpose to find a two-factor explanation of motivation. In one group of needs are such thighs as company policy and administration, supervision, working condition, inter-personal relations, salary, status, job security and personal life. These were found by Hertzberg and his associates to e only "dissatisfies" and not motivators. In other words, if they exist in a working environment in high quantity and quality, they yield no dissatisfaction. However, their existence does not motivate in the sense of yielding satisfaction; their lack of existence would result in dissatisfaction. 
In the second group Hertzberg listed certain "satisfiers" and therefore motivators, all related to job content. These include the factors of achievement, recognition, challenging work, advancement and growth in the job. He acclaims that the existence of all these aforementioned factors will yield feelings of satisfaction or no satisfaction at all (not dissatisfaction).

The first group of factors, Hertzberg describes it as "maintenance" or hygiene" factors. Their presence will not motivate people in an organization; yet they must be present, or dissatisfaction will arise. Also, as he makes it clear, that motivation will not be very effectives if hygiene factors are missing. The second group, or the "job content" factors, is found to be the real motivator because they have the potential pf yielding a sense of satisfaction. Basically, if this theory of motivation is sound, it then means that the manager must give a considerable attention to upgrading job content. (Brayfield, A and Crockett, W. 1995).

Maslow's Need Hierarchy

\begin{tabular}{|ll|}
\hline Self-actualization & Challenging work achievement growth in the job \\
\hline Esteem or status & Advancement, status recognition \\
\hline Affiliation or acceptance & $\begin{array}{c}\text { Interpretational relations, company policy and } \\
\text { administration, quality of supervision. }\end{array}$ \\
\hline Security or Safety & $\begin{array}{c}\text { Quality of work supervision. Working supervision } \\
\text { Working conditions, job security salary, personal } \\
\text { Life. }\end{array}$ \\
\hline Physiological needs & Salary, personal life. \\
\hline
\end{tabular}

Adapted from the work of Hertzberg and his associates; job Attitude:

Reviewed of Research and Opinion (1987) McClelland's learned Needs Model: A Content Approach

McClelland's theory assumes that certain individual needs are a reflection of society's cultural values and are acquired in childhood. This, the behaviour associated with satisfying the need in adult life is something is kin to a culturally induced personality trait. (Dereck, $R$ et. al 1998).

Hellriegel, et. al, (1996) postulates that David McClelland's leaned needs model specifies that people acquire three important needs or motives achievement affiliation and power-through interaction with their surrounding environments. In other words, the social contexts in which people live and work influence the learning and strength of these motives.

Hellriegel and his co-scholars achievement need as the desires to succeed relative to some standard of excellence or in competitive situation. He adds that individuals with a high need achievement often like to assume personal responsibility for setting their goals, prefer to pursue moderately difficult goals, and desire immediate and concrete feedback. The Affiliation needs is a person's desire to develop and maintain close, mutual satisfying interpersonal relationships with others. Individuals with a strong affiliation motive tend to seek approval and reassurance from others and conform to group norms, others and the social environment. The need for power is an individual's desire to influence and control others and the social environment. The power motive manifests itself in two ways; as personal power and as socialized power. With personal power, individual try to influence and control others merely to assert their dominance. With social power, individual use their power to solve organization's problem and help the organization reach its goals.

The favorable research study of Iyuyi Misumi and Fumiyasuseki (1971), effects of Achievement Motivation on the effectiveness of leadership patterns. The purpose of the study was to find out, under experimental conditions, the effect of varying the strengths of need for achievement ( $\mathrm{n}$-Ach) individual of $\mathrm{s}$ group on the effectiveness of four types of supervisory behaviour or leadership patterns with respect to the productivity and satisfaction of the groups.

McClelland et. al (1993), in Iyuyi Misumi and Fumiseyi Sekin (1971) journey of administrative science, develops a scoring formula for $\mathrm{n}$-Ach based on the thematic appreciative measures.

Atkinson (1966), conjectures that in the case of person with strong motivation, the more difficult the task to be performed, the higher satisfaction with their work.

\section{History Of Lagos State University}

The Lagos State University - also known as LASU - was established in 1983 by the enabling Law of Lagos State of Nigeria, for the advancement of learning and establishment of academic excellence. The university caters for a population of over 61,000, enrolled in full-time and part-time programmes at the Diploma, Undergraduate and Postgraduate. Lagos State University (informally LASU), located in the city of Ojo, Lagos, Nigeria, is the only state university in the former British colony. The Vice-Chancellor is Professor John Oladapo Obafunwa. Lagos State University was conceived as a multi-campus, collegiate and nonresidential University. Today, Lagos State University operates a multi-campus system with four fully owned campuses having its main campus at Ojo (along the Badagry Expressway) and other campuses at Epe (where the Engineering Faculty is located), Ikeja and Surulere, as well as nine external/affiliated campuses: Anthony, Jibowu, Agege, Lekki, Isolo, Ikoyi, Ikorodu, Festac, Badagry campuses and the external system also coordinate the sandwich programme of the school and the new Director of the programme is Prof Abanikonda, an articulate 
and the evolutional leader. The former Ag. Vice Chancellor of the university Professor Ibiyemi Olatunji-Bello has embarked on a voyage of rebranding the university through the building of hostels within the Ojo Campus and the construction of a Private Virtual Network (PVN) and she has also make efforts to put the University in its rightful leading position in various disciplines particular Law and Medicine during her tenure.

\section{Methodology}

This research study will basically make use of primary data that would be used in generating questionnaire which will be administered to resource person lecturing in Lagos State University, External System across the campus (Isolo, Jibowu, Anthony, Ikoyi, Ikorodu, Agege, Badagry, Lekki, Fetac campuses of LASU).

However, the study population comprises 150 resource person of Lagos State University, External System across the campuses in Lagos environment and it is made up of male and female altogether. More so, the population also has different material status from single to married employees.

Further more, Spearman's rank correlation coefficient will be adopted in this study. Spearman's rank correlation coefficient or Spearman's rho, named after Charles Spearman and often denoted by the Greek letter $\rho_{\text {(rho) or as, is a non-parametric measure of statistical dependence between two variables. It assesses how well }}$ the relationship between two variables can be described using a monotonic function. If there are no repeated data values, a perfect Spearman correlation of +1 or -1 occurs when each of the variables is a perfect monotone function of the other. Therefore Spearman's coefficient can be used when both dependent (outcome; response) variable and independent (predictor) variable are ordinal numeric, or when one variable is a ordinal numeric and the other is a continuous variable. However, it can also be appropriate to use Spearman's correlation when both variables are continuous and the formular is as follows;

$\mathrm{R}=1-\frac{6 \sum \mathrm{d}^{2}}{\mathrm{n}\left(\mathrm{n}^{2}-1\right)}$

$$
\overline{\mathrm{n}\left(\mathrm{n}^{2}-1\right)}
$$

Where $d=$ the difference between the ranks of each pair.

$\mathrm{n}=$ number of paired observations

\begin{tabular}{l|l|l|}
\hline \multicolumn{1}{|c|}{ Correlation Range } & Strength of Association \\
\hline \pm 0.70 to \pm 1.00 & Strong \\
\hline \pm 0.40 to \pm 0.69 & Moderate \\
\hline \pm 0.25 to \pm 0.39 & Weak \\
\hline \pm 0.10 to \pm 0.24 & Very Weak \\
\hline \pm 0.00 to \pm 0.09 & None \\
\hline Source: &
\end{tabular}

\section{Research Hypotheses}

HYPOTHESIS ONE

Null Hypothesis (Ho): Motivation has no significant effect on Lecturer's Performance in Lagos State University External System.

Alternative Hypothesis (H1): Motivation has a significant effect on Lecturer's Performance in Lagos State University External System.

\section{Hypothesis Two:}

Null Hypothesis (Ho): Job satisfaction has not enhances productivity among the lecturer's in Lagos State University, External system.

Alternative Hypothesis (Ho): Job satisfaction has enhances productivity among the lecturer's in Lagos State University, External system.

\section{ANALYSIS}

Table 1: Sex Distribution

\begin{tabular}{|l|l|r|l|}
\hline Responses & Frequency & CF & Percentage \\
\hline Male & $\mathbf{7 9}$ & $\mathbf{7 9 . 0}$ & $\mathbf{5 2 . 7}$ \\
\hline Female & $\mathbf{7 1}$ & $\mathbf{1 5 0 . 0}$ & 47.3 \\
\hline Total & 150 & & 100 \\
\hline
\end{tabular}

Source: Field survey 2012

The table above shows that 79 out of 150 respondents are male and this gives $52.7 \%$ of the total respondents while 71 out of 150 respondents are female and this gives $47.3 \%$ of the whole respondents. Therefore, we can then conclude that there are more male respondents than female respondents in this research study. 
Table 2: Age Distribution

\begin{tabular}{|l|l|c|c|}
\hline Responses & Frequency & CF & Percentage \\
\hline $23-30$ & 39 & 39.0 & 26.00 \\
\hline $31-35$ & 62 & 101.0 & 41.33 \\
\hline $36-40$ & 37 & 138.0 & 24.67 \\
\hline 41 above & 12 & 150.0 & 8.00 \\
\hline Total & 150 & & 100.0 \\
\hline
\end{tabular}

Source: Field survey 2012

The above table shows age distribution of the respondents whose age varies between 23 and 41 above. The age frequency of 23-30yrs was 39 respondents which represents $25 \%$ of the whole respondents, 31-35yrs of age frequency was 62 and this gives $41.3 \%$ of the total respondents, employees ranging from 36-40yrs was 37 in number and it represents $24.7 \%$ of the whole respondents while respondents whose age are 41 and above was only 12 and this gives $8 \%$ of the total respondents, which is very scanty in number. Therefore we can then conclude that respondents between the age of 31-35 years are more in the research study.

Table 3: Presentation of Marital Status

\begin{tabular}{|l|l|c|l|}
\hline Responses & Frequency & CF & Percentage \\
\hline Single & 64 & 64.0 & 42.7 \\
\hline Married & 86 & 150.0 & 57.3 \\
\hline Total & 150 & & 100 \\
\hline
\end{tabular}

Source: Field survey 2012

Form the above table shows that the set of data depicts that marital status data, for single was 64 out of 150 respondents were 86 out of 150 and this gives $57.3 \%$ of the whole respondents. From the analysis above we can conclude that there are more married respondents in the research study.

Table 4: Presentation of Educational Qualification

\begin{tabular}{|l|l|c|l|}
\hline Responses & Frequency & CF & Percentage \\
\hline B.Sc/B.A & 51 & $\mathbf{5 1 . 0}$ & $\mathbf{3 4 . 0}$ \\
\hline MBA & 43 & 94.0 & 28.7 \\
\hline Professional & 30 & 124.0 & 20.0 \\
\hline PhD & 26 & 150.0 & 17.3 \\
\hline Total & 150 & & 100.0 \\
\hline
\end{tabular}

Source: Field survey 2012

The above frequency table shows the educational qualification of the study population. It indicates that employees who had B. Sc, B.A or its equivalent are 43 out of 150 respondents and this gives $28.7 \%$ of the whole respondents, while Masters in Business Administration (M. BA) or it equivalent are 51 out of 150 respondents and it represents $34 \%$ of the total respondents while those that had professional qualifications such as ICAN, CIS, CIBN etc ar3 30 out of 150 respondents which gives $20 \%$ of the whole respondents and that of $\mathrm{PhD}$ are 26 out of 150 respondents and this represent $17.3 \%$ of the total respondents. However, we can then infer from the result above that majority of the respondents are graduate.

TABLE 5 RESULT OF GENERAL QUESTIONS DISTRIBUTED TO THE RESPONDENTS

\begin{tabular}{|c|c|c|c|c|}
\hline Questions & Response & Frequency & $\begin{array}{l}\text { Cumulative } \\
\text { Frequency }\end{array}$ & $\begin{array}{l}\text { Percentage } \\
(\%)\end{array}$ \\
\hline $\begin{array}{l}\text { 1. Motivation is the key to organizational } \\
\text { performance }\end{array}$ & $\begin{array}{l}\text { COLUMN } \\
\text { SA } \\
\text { A } \\
\text { SD } \\
\text { D }\end{array}$ & $\begin{array}{l}148 \\
2 \\
- \\
-\end{array}$ & $\begin{array}{l}148.0 \\
150.0\end{array}$ & $\begin{array}{r}98.67 \% \\
1.33 \%\end{array}$ \\
\hline $\begin{array}{l}\text { 2. Leadership in Lagos State University, } \\
\text { External System has improved lecturer } \\
\text { dedication to work. }\end{array}$ & $\begin{array}{l}\text { SA } \\
\text { A } \\
\text { SD } \\
\text { D }\end{array}$ & $\begin{array}{l}- \\
- \\
150 \\
-\end{array}$ & $\begin{array}{c}- \\
- \\
150.0 \\
-\end{array}$ & $\begin{array}{c}- \\
- \\
100.0 \\
-\end{array}$ \\
\hline $\begin{array}{l}\text { 3. Motivation has improve lecturer's } \\
\text { Performance in LASU, External System. }\end{array}$ & $\begin{array}{l}\text { SA } \\
\text { A } \\
\text { SD } \\
\text { D }\end{array}$ & $\begin{array}{l}- \\
- \\
150 \\
-\end{array}$ & 150.0 & 100.0 \\
\hline $\begin{array}{l}\text { 4. Resource Persons Motivation has } \\
\text { Maintain stability and Growth in LASU, } \\
\text { External System. }\end{array}$ & $\begin{array}{l}\text { SA } \\
\text { A } \\
\text { SD } \\
\text { D }\end{array}$ & $\begin{array}{l}- \\
- \\
150 \\
-\end{array}$ & 150.0 & 100.0 \\
\hline
\end{tabular}


Motivation, An Engine For Organizational Performance, A Case Study Of Lagos Tate University,

\begin{tabular}{|c|c|c|c|c|}
\hline $\begin{array}{l}\text { 5. Poor Leadership Performance has } \\
\text { negative impact on employee's motivation. }\end{array}$ & $\begin{array}{l}\text { SA } \\
\text { A } \\
\text { SD } \\
\text { D }\end{array}$ & $\begin{array}{l}150 \\
- \\
- \\
-\end{array}$ & 150.0 & 100.0 \\
\hline $\begin{array}{l}\text { 6. Bad Welfarism is an Obstacle for } \\
\text { employee's performance and poor } \\
\text { productivity in an Organization. }\end{array}$ & $\begin{array}{l}\text { SA } \\
\text { A } \\
\text { SD } \\
\text { D }\end{array}$ & $\begin{array}{r}120 \\
10 \\
-\quad 20\end{array}$ & $\begin{array}{l}120.0 \\
130.0 \\
150.0\end{array}$ & $\begin{array}{r}80.00 \\
6.67 \\
13.33\end{array}$ \\
\hline $\begin{array}{l}\text { 7. Motivation leads to employees putting } \\
\text { their best for the organization and } \\
\text { leadership improve the activities of } \\
\text { production of the organization. }\end{array}$ & $\begin{array}{l}\text { SA } \\
\text { A } \\
\text { SD } \\
\text { D }\end{array}$ & $\begin{array}{l}150 \\
- \\
- \\
-\end{array}$ & 150.0 & 100.0 \\
\hline $\begin{array}{l}\text { 8. Motivational Package is an Engine for } \\
\text { resource persons Performance in LASU, } \\
\text { External System. }\end{array}$ & $\begin{array}{l}\text { SA } \\
\text { A } \\
\text { SD } \\
\text { D }\end{array}$ & $\begin{array}{l}\mathbf{1 0 0} \\
\mathbf{5 0} \\
- \\
-\end{array}$ & $\begin{array}{l}100.0 \\
150.0\end{array}$ & $\begin{array}{l}66.67 \\
33.33\end{array}$ \\
\hline $\begin{array}{l}\text { 9. Motivation in LASU, External System can } \\
\text { be described has good and better. }\end{array}$ & $\begin{array}{l}\text { SA } \\
\text { A } \\
\text { SD } \\
\text { D }\end{array}$ & $\begin{array}{l}- \\
- \\
150 \\
-\end{array}$ & 150.0 & 100.0 \\
\hline $\begin{array}{l}\text { 10. LASU, External System has a good } \\
\text { leadership that looks after the welfare of } \\
\text { resource person from time to time. }\end{array}$ & $\begin{array}{l}\text { SA } \\
\text { A } \\
\text { SD } \\
\text { D }\end{array}$ & $\begin{array}{l}- \\
22 \\
88 \\
40\end{array}$ & $\begin{array}{r}- \\
22.0 \\
110.0 \\
150.0\end{array}$ & $\begin{array}{l}- \\
14.67 \\
58.67 \\
26.66\end{array}$ \\
\hline $\begin{array}{l}\text { 11. Some resource Person in LASU, } \\
\text { External System are not dedicated to work } \\
\text { because of poor remuneration, late in } \\
\text { payment of honoraria, poor leadership } \\
\text { across the campuses, poor allocation of } \\
\text { courses to wrong resource persons and poor } \\
\text { communication system in disseminating } \\
\text { information. }\end{array}$ & $\begin{array}{l}\text { SA } \\
\text { A } \\
\text { SD } \\
\text { D }\end{array}$ & 150 & 150.0 & 100.0 \\
\hline $\begin{array}{l}\text { 12. Poor Motivation of resource person has } \\
\text { leads to decline in the standard of Education } \\
\text { in the part time programme in LASU across } \\
\text { the campuses. }\end{array}$ & $\begin{array}{l}\text { SA } \\
\text { A } \\
\text { SD } \\
\text { D }\end{array}$ & $\begin{array}{r}120 \\
30\end{array}$ & $\begin{array}{l}120.0 \\
150.0\end{array}$ & $\begin{array}{r}80.0 \\
100.0\end{array}$ \\
\hline $\begin{array}{l}\text { 13. Job satisfaction has enhances } \\
\text { productivity among the resource person in } \\
\text { Lagos State University, External system. }\end{array}$ & $\begin{array}{l}\text { SA } \\
\text { A } \\
\text { SD } \\
\text { D }\end{array}$ & $\begin{array}{c}- \\
- \\
150 \\
-\end{array}$ & $\begin{array}{c}- \\
- \\
150.0\end{array}$ & 100.0 \\
\hline $\begin{array}{l}\text { 14. LASU, External System Educational } \\
\text { standard has been Enhanced now than } \\
\text { Before. }\end{array}$ & $\begin{array}{l}\text { SA } \\
\text { A } \\
\text { SD } \\
\text { D }\end{array}$ & $\begin{array}{l}- \\
76 \\
74 \\
-\end{array}$ & $\begin{array}{r}76.0 \\
150.0\end{array}$ & $\begin{array}{l}50.67 \\
49.33\end{array}$ \\
\hline $\begin{array}{l}\text { 15. The input of both the Vice chancellor } \\
\text { and the Director of the Programme has } \\
\text { improved LASU, External System now } \\
\text { than before. }\end{array}$ & $\begin{array}{l}\text { SA } \\
\text { A } \\
\text { SD } \\
\text { D }\end{array}$ & $\begin{array}{l}- \\
77 \\
73\end{array}$ & $\begin{array}{r}77.0 \\
150.0\end{array}$ & $\begin{array}{l}51.33 \\
48.67\end{array}$ \\
\hline Total & & 150 & & 100.0 \\
\hline
\end{tabular}

Source: Field survey 2012

Where SA- Strongly Agree, A- Agree, SD- Strongly Disagree, D- Disagree, LASU- Lagos State University. The table above shows in question (1) that 148 out of 150 respondents strongly agree with notion and this gives $98.67 \%$ of the whole respondents while 2 out 150 respondents only agree with the notion, therefore we can conclude that motivation is a key to organizational performance, but in question (2) it was revealed that all the respondents strongly disagree with the question and this means that Leadership in Lagos State University, External System has not improved lecturer dedication to work because the resource person are not considered as part and parcel of the school. In question (3), all the respondents strongly disagree that motivation has improved 
lecturer's Performance in LASU, External System and according to some of them is no motivation at all from the part of the leadership of LASU, external system and in question (4) since there was no motivational package for the resource person (lecturers) so all the respondents disagree that resource Persons motivation has maintain stability and growth in LASU, External System.

However, in question (5) all the respondents strongly agree that Poor Leadership Performance has negative impact on employee's motivation, in question (6) 120 out of 150 respondents strongly agree with the notion while 10 out of 150 respondents agree with the notion but 20 respondents disagree with the question, therefore we can conclude from the analysis that bad welfarism is an Obstacle for employee's performance and poor productivity in an Organization. More so, in question (7) all the respondents strongly agree that motivation leads to employees putting their best for the organization and leadership improve the activities of production of the organization, but in question (8) 100 and 50 respondents agree that motivational Package is an Engine for resource persons Performance in LASU, External System. In question (9) all the respondents strongly disagree with the question and we can then conclude that motivation in LASU, External System cannot be described has good and better while in question (10) 22 respondents agree with the notion, 88 respondents strongly disagree with the notion while 40 respondents disagree with the notion, we can conclude from the analysis that LASU, External System has a bad leadership that dose not looks after the welfare of resource person (lecturers) from time to time. In question (11) all the respondents strongly disagree with the notion and we can then conclude that resource Person in LASU, External System are not dedicated to work because of poor remuneration, late in payment of honoraria, poor leadership across the campuses, poor allocation of courses to wrong resource persons and poor communication system disseminate information.

Further more, in question (12) 120 and 30 respondents agree with the notion and we can deduced from the analysis that Poor Motivation of resource person has leads to decline in the standard of Education in the part time programme in LASU across the campuses while in question (13) all the respondents strongly disagree with the question, therefore we can conclude that initial there is no Job satisfaction among the resource person (lecturers) in LASU, external system so therefore productivity cannot be enhanced among.

More over, in question (14) 76 respondents agree with the question while 74 respondents disagree with the question, and we then conclude that LASU, External System Educational standard has been enhanced now than before, but the analysis is very close because some of the respondents only agree while some strongly disagree with the question, while in question (15) 77 respondents agree with the question while 73 respondents strongly disagree with the question, we can then conclude that the input of both the Vice chancellor and the Director of the Programme has improved LASU,

External System now than before, the conclusion can be questionable because the ratio of agree to disagree is very close, some of the respondents belief that the result of the questionnaire in question 14 and 15 did not reflect the true situation of the system, therefore we can only conclude on the result of our questionnaire we collected.

\begin{tabular}{|c|c|c|c|c|}
\hline 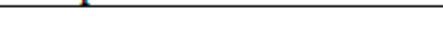 & Q1 & Q9 & Q1 & Q9 \\
\hline $\begin{array}{lrr}\text { Spearman's } & \text { rho } & \text { Q1 } \\
\text { Correlation } & \text { Coefficient } & \text { Sig. } \\
\text { (2-tailed) } & & \\
\text { N } & & \end{array}$ & $\begin{array}{l}1.000 \\
150\end{array}$ & $\begin{array}{l}.897 * * \\
150\end{array}$ & $\begin{array}{l}1.000 \\
150\end{array}$ & $.022 * *$ \\
\hline $\mathrm{Q}^{9}$ Correlation $\mathrm{C}$ & $\begin{array}{l}.897^{* *} \\
150\end{array}$ & $\begin{array}{l}1.000 \\
150\end{array}$ & $.022 * *$ & $\begin{array}{l}1.000 \\
150\end{array}$ \\
\hline
\end{tabular}

Source: SPSS Package

Decision Rule: If the Spearman's rank correlation H calculated is greater than Spearman's rank correlation $\mathrm{H}$ tabulated, we accept the alternative hypothesis and reject the null hypothesis. The tabulated value use here is $5 \%$ level of significance that is $* * \mathrm{P}<0.05$ and vice versa. However, it was revealed from the result above that the spearman's rank correlation coefficient results for research hypothesis one, and two values is given as 0.897 which established that there is a positive and strong relationships while 0.081 shows that there no correlation at all and no relationship is established.

More over, since the spearman's rank correlation coefficient calculated value 0.897 and is greater than Spearman's rank correlation coefficient tabulated value using $5 \%$ level of significance ** $\mathrm{P}<0.05$ we then accept alternative hypothesis in hypothesis one and reject the null hypothesis, then conclude that Motivation has a significant effect on Lecturer's Performance in Lagos State University External System, according to the questionnaire and analysis it was known that motivation is the key for majority of the resource person (lecturers) to perform well. More over, since the spearman's rank correlation coefficient calculated value is 0.022 and is less than the spearman's rank correlation coefficient tabulated value using $5 \%$ level of significance of $* * \mathrm{P}<$ 0.05 , we then accept the null hypothesis and reject the alternative hypothesis, then conclude that Job 
satisfaction has not enhances productivity among the lecturer's in Lagos State University, External system, according to our analysis in the questionnaire we collated and the results, it was shown vividly that many resource person (lecturers) in LASU external system are not happy with the system and the way the system is operating has not make many of them to put in their best and in organization theory any worker that is not happy on job will not put in his/her best, because the theory says a happy worker is a productive worker.

\section{Recommendations}

\section{Recommendations And Conclusion}

In the light of this research study, the following suggestions and recommendations are made: Management executives of Lagos state university, External system should recognize and identify those set of factors that perhaps boost employees morale, make them have love and belongingness, recognition while associating themselves with any organization. Organizational Development and Management should do much to sharpen motives by establishing an environment conducive to certain drives. For instance, a resource person (lecturer) that developed a reputation for excellence and high quality tend to be motivated to contribute to the development of the part time programme in LASU. Similarly, the environment of a business/school in which managerial performance is intelligent and effective tends to bread a desire for high-quality management in the entire system.

Management executives of LASU, External system should also take cognizance of resource person (lecturer) inputs as well as their involvement in goal setting because it is through this they will be motivated and therefore facilitate their performance.

For any system that want to maintain a high level of performance in a highly variable-external and competitive environment should also note those maintenance or hygiene factors such as school policy, and administrations, supervision, working conditions, interpersonal relations, salary, status, job security among others, although their presence will not motivate employee/lecturers in an organization, yet they must be present, otherwise job dissatisfaction will setting-in. However, the school authority should also make effortperformance-reward visible to the resource person (lectures) in external system and concentrate or focus their attention on it. Thus, it is no use persuading the resource person (lecturers) to work hard, increase their effort, if they can see that they will not be able to achieve the results by which their performance will not be judged.

On a last note, to increase and improve employees/lecturers' productivity, make them committed to the goals of the organization/school; managers of LASU, external system should focus their attention on the following if they are to bring the best out of their resource person (lecturers) in external system of the school:

(i) Institute pay-for-performance plan, paying for meritorious work.

(ii) Design jobs so as to make the desired performance more attainable.

(iii) Allowing the resource person to select the fringe benefits they most value.

(iv) Administer rewards that have a high positive valence to workers.

(v) Allocate courses to those that can deliver to the students.

(vi) Prompt payment of honoraria at when due and other payments inclusive.

(vii) Employment letter and staff Identity card should be given to all the resource person (lecturers) in external system, to make them feel they are part and parcel of the system.

(viii) Student result should be computed on time and let them (student) be able to use their result employment opportunity.

(ix) Resource person (lecturers) in external system should be given opportunity to invigilate the student examination not some people that are not in the system.

(x) The Director of the programme should take the resource person (lecturers) as his own colleagues not as mere tools of production.

\section{Conclusion}

My deductions would be made from previous studies, especially from my literature review, and from results of my findings. However, motivation, and employees' job satisfaction is one of the key factors to organizational development be it a company or an academic environment. According to Fredrick Taylor, (Hackett, 1979), the first person to give serious thought to why people work, or, more specially, how they could be made to work harder, such a company would therefore achieve credible performance. Therefore, the research study was able to establish that motivation is essentially an explanatory concept, and is used to explain why a person behaves in a certain way and, in particular, to describe three component of behaviour which have an impact on performance. These components are:

(i) direction of behaviour, which is greatly influenced by what a person most desires to do;

(ii) intensity of behaviour, which roughly equates to how hard the individual strives to go in that direction; and

(iii) persistence, which consists of the individual's willingness to pay with the direction when obstacles are encountered (Derek, et. al 1998). 
Motivation are found to be an imperative tool for management practitioners as well as organizational behaviorists. It was discovered that work motivation in a work environment brings higher performance and ultimately lead to higher productivity for the organization at large. Most importantly, working conditions, status, company procedures, quality of work supervision and interpersonal relations are "hygiene factors" which when present in a work environment, bring job satisfaction. These and many more are what this study was able to discover.

This research study shows that money and increase in pay to employee/lecturer in LASU, external system is the crucial incentive to work motivation. As a medium of exchange, it is the vehicle by which resource person (lecturers) can purchase their numerous needs and satisfying their desires to support their other job because the standard of living in Lagos environment and Nigeria as a whole is very high. It also demonstrated that money performs the function of a scorecard, by which employees can compare their values to others.

Also, it establishes that employees'/lecturers' involvement in participative management and affairs of the organization makes them have a good sense of belonging afford them the opportunity to know where they stand with the organization/school. The research was able to find out that employees' involvement has some underlying logic, that is, involving workers in those decisions that affect them and by increasing their autonomy and control over their work lives, employees/lecturer will becomes more motivated, more committed to the organization/school of part time, LASU, more productive and more satisfied with their jobs.

Further more, introduction of motivation provides answers to such questions explaining why employees/lecturers behave as they do in organizations. It demonstrates also that employees/lecturers input such as efforts, specific job behaviour, skills, knowledge, time and experience give desirable inputs which influence job performance and, ultimately organizational performance (George J. and Gareth J. 1999). This study concludes that motivating go along way to subordinate work, increasing and enhancing their performance and gives room for employees' job satisfaction. It discovers that employees have need for affection, achievement, recognition, and advancement at work and any attempt that makes all these not present will cause job dissatisfaction to employees, LASU, external system and corporate organizations must not overlook this vital aspect of realizing higher productivity from lecturer/employees. Worthy of note is that when employees are not fulfilled or achieve their goals, it is difficult for an organization to achieve its goals, so the resource person (lecturers) in LASU, should be treated better so that they will put in their best for the upliftnment of the school.

\section{References}

[1] Asika, N.(1991) Research Methodology in the Behavioural Science. Lagos, $2^{\text {nd }}$ edition, pg 32-54. Longman Nigerian Plc.

[2] Atkinson B (1968) Organization and Employees commitment, a wider perspectives, $2^{\text {nd }}$ edition, pg 22-31, Bolu Bestway Printers.

[3] Banjoko, S.A. (2002) Human Resources Management an Explository, Approach, a textbook $2^{\text {nd }}$

[4] edition, pg 33-45, Pumark Nigeria Limited.

[5] Bowditch, J.L. and Buono A.F. (1997): A premier on organizational performance, a journal of social science, University of Lagos, Vol. 4, page 1-30, University of Lagos press Motivation and Leadership in Swedan, a journal of University in Sweden, $4^{\text {th }}$ edition, John and sons press

[6] Betz, Milkerich and Read (1992) Rating Segmentation of Workers attitude in an Organization, Journal vol 2, issue 1, pg 78-91, Melt world Publication, limited.

[7] Brayfield A and Crockette, W (1995) The theory of Motivation in a larger perspective, textbook $2^{\text {nd }}$ edition, pg 34-41, Mac and Mac Publication limited.

[8] Casmir .I. (2005) managing human resources for greater profitability. The punch newspaper march $14^{\text {th }}, 2005$

[9] Chete F. (1999) The impact of leadership on organizational performance A university of Tanzania pres publication, 1999

[10] Casmir I.(2005) Managing Human Resources for Greater Profitability. The Punch Newspaper March $14^{\text {th }}, 2005$.

[11] Campbell and Pritched et al (1976) Impact of motivation and organization Prospects, textbook, $2^{\text {nd }}$ edition, pg 118-127, BBT Press limited.Davids, K. (1978) Human Behaviour at Work-Organization, Journal of Social Science, vol 2, pg 113-142, San Francisco, Canfield Press.

[12] Davis, K. (1978) Human behaviour at work-organisation. Francosco. San, Canfield press

[13] Davis, K. (1978), Human bahaviour at work- organization. San Francisco University, Canifield press.

[14] Derk et al (1998) Work Motivation in an Organization, textbook, $4^{\text {th }}$ edition, pg 55-69, Macgraw Hill world Press limited

[15] Douglas A. Lind (1993) Robbins S.P, (1989) Organization Behaviour Prentice Hall International, Englewood Cliffs, $4^{\text {th }}$ Edition, 1989.Elton M (2004). Hawthrone Experiment on productivity and motivation.http.//www EltonMayon-HA wthrone.htm.

[16] Fajana, S. (2002) Human Resources Management. Lagos, $2^{\text {nd }}$ edition, pg 22-331, Labofiin and Company, limited.

[17] Falegan(2000) Motivation and Leadership, a propel to organizational A university of

[18] Ibadan social science publication, 2000, university press Ibadan.

[19] Gbadamosi, G. and Adebankin, M.A. (1997) Organizational behaviour, a text book basic introduction, on organizational behaviour, $4^{\text {th }}$ edition pumark Nigeria limited (educational publishers).

[20] Green, C. (1972) the satisfaction performance controversy, business horizons, a textbook, on business times, $3^{\text {rd }}$ edition pages $2-23$.

[21] Gareth and George (1999) Organizational behavior and its implication on employees' Performance, vol 6, issue 3, Macmillam Publication limited, London.

[22] Hackett F (1979) Motivation and Leadership, in an Organization, textbook $2^{\text {nd }}$ edition, pg 10-18, Bell Press incorporated

[23] Herzberg, F. (1996) Work and the Nature of Man, $4^{\text {th }}$ edition, pg 118-127, Cleveland. World

[24] Publishing Company.Hellriegel et al (1996) Motive of Motivation in broader perspective, $2^{\text {nd }}$ edition, MMT Press.

[25] Hodgetta, R. (1977) Introduction of Business, $2^{\text {nd }}$ edition, pg 22-37, Addison Wesley Publishing 
[26] Company.Harper, Row Mason R. and Lind D.A. (1993) Statistical Tecniques in Business and Economics. $1^{\text {ST }}$ edition, pg 11-21, Homewood Publication limited. Igbokwe C. (2005): Managing Human Resources for Greater Profitability. The punch Newspaper March $14^{\text {th }}, 2005$

[27] Illonois, Richard D. Irwin and Mayo E. (1985) The Social Problem of an Industral Civilization.a

[28] Journal of University of Boston, vol 8, pg 44-52, Harvard Publication limited.

[29] Iyuyimisumi and Fumiyasueki (1971) Impact of Motivation on organizational Performance, Journal of Management Sciences, vol 3, pg 22-31, Hill world Press.

[30] Jonathan Michie et.al (2002) Employees Ownership, Motivation and Productivity, Research Report for Employees Direct form Brikbeck and the Work Foundation,Macmillan Publication.

[31] Koontz et al (1980) Two Factor Explanation of Motivation in an organization, textbook $2^{\text {nd }}$ edition, pg 13-22, Melt world Press.

[32] Kuye M (2001) Motivational Package as a means for employees Performance in an Organization, conference on Managers involvement in an organization, held at Sheraton tower, Lagos.

[33] Likert, R. (1961) New Patterns of Management, $1^{\text {st }}$ edition, pg 13-19, New York McGraw-Hill Book Company.Lacke F (2002) Job Satisfaction and Employess performance in a multi-corporation, Journal of Management Sciences, College of High wall, BBT Publication limited.

[34] Land and Fair (1980), Murply, K (1995) Leadership and the Subordinate, textbook $2^{\text {nd }}$ edition, pg 66-74, BBT Publication limited.

[35] Lawler, E. and Porter, L. (1968) Managerial attitudes and performance, a journal of University of Illinois, Volume 3, page 22-50, Macgraw Hill Publication.

[36] Lawrence, P. and Sieler, J. (1965): Organization Behaviour and administration, a journal of Illinois University U.S.A, Volume 4, pages 1-33, Illonois press Limited.Likert, R. (1963) Human Organization behaviour, $3^{\text {rd }}$ edition, pg 43-52, New York McGraw-

[37] Hill Book company.

[38] Luther D (2002) Impact of Motivation on Lecturers' Performance in a Secondary School, textbook, $2^{\text {nd }}$ edition, pg 55-64, Ted world Press limited.

[39] Nyang A (2005) Introduction to Research Methodology, $1^{\text {st }}$ edition, pg 43-46, Bolu Bestway Printers.

[40] Maslow, A. (1954) Impact of Motivation on Leadership Personality, a Journal of Socia Sciences, vol 9, pg 23-43, New York Publication Limited.

[41] McCelland, D. (1993) Achievement Motive. $3^{\text {rd }}$ edition, pg 21-32, New York, Appleton-Century Crofts, Inc.McCregor, and Douglas (1957) Impact of Motivation and Human Side of Enterprise Management, Journal of university of Sweden, Vol. 40, no 11, pg 66-74, Mhill Publication limited.

[42] McCuddy, K (2001) Organization and Employees dissatisfaction, $2^{\text {nd }}$ edition, pg 22-34, Macmillan Publication limited.

[43] Marriot, R.(1997) Incentive Payment System, textbook $3^{\text {rd }}$ edition, pg 65-71, Carrington press, India.

[44] Maslow, A. (1999) Motivation and Personality, New York. Harper And Row Mayo E. (1995)

[45] The Social Problem of an Industrial Civilization. Boston, Harvard University Press.

[46] McCelland, D. (1999) Achievement Motive, $4^{\text {th }}$ edition, pg 22-31, New York. Appleton-CenturyCrofts, Inc.

[47] McGregor, D. (2007) The Human Side of Enterprise Management, University of New York,

[48] Vol. 40, No11, pg 23-34, New York Publication limited.Obisi C. (1996) Personal Management, textbook, $2^{\text {nd }}$ edition, pg 23-31, Jackbod Enterprises limited.Punch Editorial (2005) On Police Welfare. The Punch Newspaper March $30^{\text {th }}, 2005$.

[49] Robbert D.M (2001) Statistical Techniques in Business Motivation, $2^{\text {nd }}$ edition, pg 44-51, Micheal Foundation Publication.

[50] Robbiun, G (1998) Impact of Motivation on employees Performance, Journal, vol 4, issue 2, pg 22 -31, MMT Publication limited.

[51] Rollinson at al (1998) Motivation and Leadership, a wider perspective, textbook, $2^{\text {nd }}$ edition, pg 12-22, Macmillan Publication limited.Taylor, K.F. (1974) Valence-Expectancy Approach to Work Motivation and Personnel, Journal of College Management, London school of business, vol 4 pg 43-53, London Press.

[52] Theresa M. Neff (1999) Importance of Employee Motivation and Job Satisfaction to Increased Productivity and Stronger Client Relationship, a Journal of New York College management, U.S. AM Vol. 2 page 3-13, New York press.

[53] Udo, Udo-Aka (2006) Measuring Productivity and Problem, Productivity in Nigeria- The proceedings of a national conference, Ibadan. (1982-1983)

[54] Vroom, V. (1964) Work and Motivation, a publication of University of New York, Vol. 6, page

[55] 22-133, New York Press Limited.Wadler and Porter (1997) The Organization and its People, textbook, $2^{\text {nd }}$ edition, pg 44-57, Series Publication limited. 